\title{
FGF7 Gene
}

National Cancer Institute

\section{Source}

National Cancer Institute. FGF7 Gene. NCI Thesaurus. Code C18570.

This gene plays a role in cellular biogenesis, growth, org anization and proliferation. It is also involved in the inhibition of apoptosis. 